\title{
Antibacterial properties of Moringa oleifera
}

\author{
Saba Shamim* and Usman Raza \\ Institute of Molecular Biology and Biotechnology (IMBB), The University of Lahore (UOL), Defence road campus, \\ off Bhobatian chowk, Lahore, Pakistan. \\ Email: sabashamimgenetics@gmail.com
}

Received 22 August 2017; Received in revised form 12 November 2018; Accepted 7 December 2018

\begin{abstract}
Moringa oleifera, considered a medicinal tree by many civilizations, owes its repute to its medicinal attributes, and in particular, to its antimicrobial properties. Different parts of this plant, including pods, stem bark, leaves, roots, and seeds contain bioactive agents such as quercetin, phenolic acids, alkaloids, flavonoids, etc. The modes of action of these bioactive agents are varied, ranging from the inhibition of enzymes to the disruption of bacterial cell membranes. The various antimicrobial properties of the plant are manifested in extracts of methanol, ethanol, hexane, chloroform, and water. Such extracts, which also display antibacterial activity against biofilms, can serve as therapeutic agents against multidrug resistant pathogens, including both Gram-negative and Gram-positive bacteria.
\end{abstract}

Keywords: Moringa oleifera, antimicrobial properties, Gram-positive bacteria, Gram-negative bacteria, bioactive agent

\section{INTRODUCTION}

Plants have been the source of many natural antimicrobial compounds since the history of mankind (Arora and Onsare, 2014). An example of such plants is Moringa oleifera Lam. (synonymous to Moringa ptreygosperma Gaertn), a highly valued medicinal plant that is often considered a "miracle tree". It belongs to the monogeneric plant family Moringaceae and grows to a height of $5-10$ meters (Morton, 1991).

It consists of 33 species, among which $M$. oleifera and Moringa peregrine (forsk) fiori. are well known species. The synonym of $M$. oleifera is $M$. pterygosperma Gaertn. Other names used for $M$. peregrine include Moringa aptera Gaertn., Moringa arabica (Lam.) Pers., Moringa zeylanica Sieb. and Balanusmyrepsica Blackm. (Lalas et al., 2012; Arora and Onsare, 2014).

The tree is widely distributed (Nadkarni, 1976; Ramachandran et al., 1980). It is commonly found near sandy beds of rivers and water bodies (Qaiser, 1973), but it adapts to a wide range of environments, ranging from the humid tropics to hot dry lands. Accordingly, it is little affected by drought (Morton, 1991) and thrives in rainfall between $250 \mathrm{~mm}$ to $3000 \mathrm{~mm}$. It tolerates both acidic and alkaline soils, adapting to soil pH of 5.0-9.0 (Palada and Changi, 2003; Anwar et al., 2007). While the tree is found in the wild, Moringa can be cultivated easily in household gardens.
According to Arora et al. (2013), the history of Moringa dates back to $150 \mathrm{~B}$. C. It is mentioned in ancient scriptures of the Egyptians, Greek, Romans, and Indians. The tree was used by ancient kings and queens in their royal diet to maintain good physical and mental health. Its leaves were given to ancient Maurians of India to remain fit and healthy in times of war. Having been used as a medicinal tree in more than 80 countries, Moringa has been reported in more than 200 local languages in the literature (Mossa, 1985; Booth and Wickens, 1988; Nikkonet al., 2003; Arora et al., 2013). below.

The taxonomic classification of $M$. oleifera is given

Kingdom: Plantae

Subkingdom: Tracheobionta

Super division: Spermatophyta

Division: Magnoliophyta

Class: Eudicots

Subclass: Rosids

Order: Brassicales

Family: Moringaceae

Genus: Moringa

Species: oleifera

Taxonomic classification of M. oleifera (Arora et al., 2013). 
The occurrence of Moringa is widespread. It has been reported in Pakistan, India, Asia minor, Africa and Saudi Arabia (Mughal et al., 1999), the Philippines, Cambodia, Central, North and South America, and the Caribbean (Morton, 1991; Anwar et al., 2007).

As a "miracle tree" (Jerri et al. 2012), different common names are used for Moringa in different countries. In Pakistan, it is called as "Sohanjana" (Qaiser, 1973; Anwar et al., 2005), whereas in the Nile valley, people called it "Shagara al Rauwaq" which means "tree for purifying" (von Maydell, 1986). Other names include the drumstick tree, horse radish tree, kelor tree, and medicinal tree (Anwar and Bhanger, 2003; Anwar et al., 2007).

\section{MORINGA OLEIFERA AS A MEDICINAL TREE}

Plants produce primary and secondary metabolites (Croteau et al., 2000; Arora et al., 2013) that have applications for different purposes, e.g. curing diseases, healing injuries, etc. Such secondary metabolites are bioactive compounds that include alkaloids, phenolics, tannins, phytosterols and terpenoids (Balandrin et al., 1985; Arora et al., 2013). The importance of different parts of the Moringa plant as a source of these useful compounds cannot be ignored (Walter et al., 2011). In many cultures, they would be considered a part of "natura nutrition". The flowers, leaves, seeds, pods, stem, and bark of the tree have high nutritional value (D'souza and Kulkarni, 1993; Anwar and Bhanger, 2003; Anwar et al., 2005; Anwar et al., 2007).

\section{Medicinal properties of $M$. oleifera}

All parts of $M$. oleifera plants possess medicinal properties. These are discussed briefly below. Figure 1 shows the M. oleifera tree and its parts.

\section{Leaves}

The leaves of $M$. oleifera are a rich source of calcium, potassium, protein, $\beta$-carotene, antioxidants (ascorbic acid, flavonoids, phenolics, carotenoids) (Dillard and German, 2000; Siddhuraju and Becker, 2003). Their inclusion in the diet increases milk production in women, and hence, the tree is often referred to as "mother's best friend" in the Philippines. Some doctors also recommend Moringa leaves to anemic patients (Estrella et al., 2000; Siddhuraju and Becker, 2003). Another medical application of Moringa leaves is as a treatment for fevers, piles, bronchitis, sore throat, ear and eyes infections, catarrh. They are also used to control blood sugar levels, reduce swelling of glands, and as a purgative. The leaves are rubbed on the temples for headaches and applied as a poultice to sores (The Wealth of India, 1962; Dahot, 1988; Morton, 1991; Makonnen et al., 1997; Fuglie, 1999; Anwar et al., 2007).

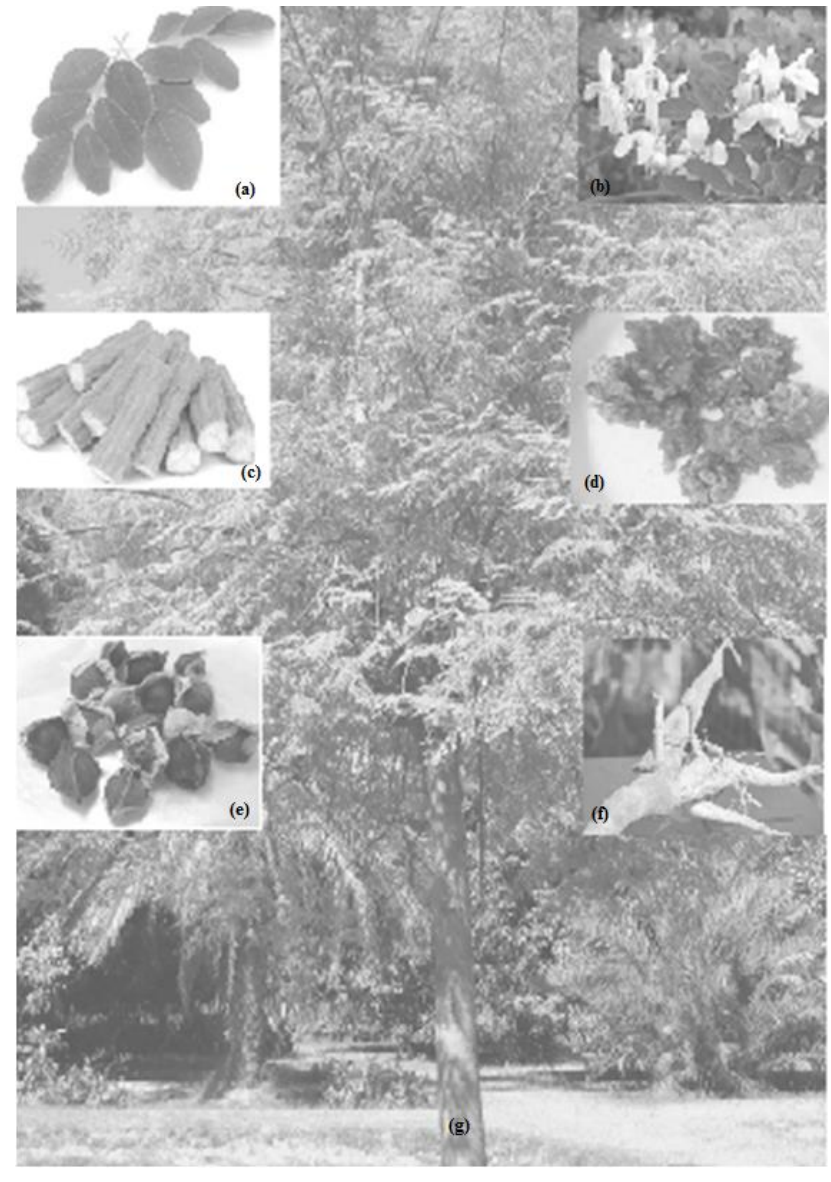

Figure 1: Figure showing $M$. oleifera tree and its different parts; (a) leaves (b) flowers (c) stem bark (d) gum (e) seeds $(\mathrm{f})$ roots $(\mathrm{g})$ tree.

\section{Roots}

Known for their medicinal properties (The Wealth of India, 1962; Padmarao et al., 1996; Dahot, 1988; Ruckmani et al., 1998; Anwar et al., 2007), Moringa roots are useful for the treatment of numerous ailments, e.g. paralytic afflictions, rheumatism, inflammations, articular pains, lower back or kidney pain and constipation. Besides being useful as a laxative, they are also act as an antilithic agent, helping the body to prevent the formation of stones in the gall bladder and kidney, as well as aiding the body in their removal. Moringa roots are also used as a carminative agent, they help to prevent or relieve flatulence. Moringa roots are useful also as antifertility, anti-inflammatory, and abortifacient agents (Anwar et al., 2007).

\section{Bark}

The bark of the Moringa stem is used to cure eye diseases. It is used also for the treatment of delirious patients, as a medication to prevent enlargement of the spleen, formation of tuberculous glands of the neck, and 
as an agent that destroys tumors and heals ulcers. The juice from the root bark is put into the ears to relieve earaches and also placed in a tooth cavity as a pain killer. It is reputed to have anti-tubercular activity (Bhatnagar et al., 1961; Siddhuraju and Becker, 2003; Anwar et al., 2007).

\section{Gums}

The gums extracted from Moringa are used for treatment of dental caries. It is an astringent. If the gum is mixed with sesame oil, it is effective for the relief of headaches, fevers, intestinal complaints, dysentery and asthma. It is sometimes used as an abortifacient, and to treat syphilis and rheumatism (Fuglie, 1999; Anwar et al., 2007).

\section{Flowers}

The flowers of Moringa are reported to possess high medicinal value as a stimulant, an aphrodisiac, an abortifacient and a cholagogue. It is used to treat inflammation, muscle diseases, hysteria, tumors, enlargement of the spleen, and to lower serum cholesterol, phospholipids, triglycerides, VLDL, LDL cholesterol to achieve a desirable phospholipid profile. It improves the atherogenic index, decreases lipid profile in hypercholesterolaemic rabbits and increases the excretion of fecal cholesterol (Bhattacharya et al., 1982; Dahot, 1998; Mehta et al., 2003; Siddhuraju and Becker, 2003; Anwar et al., 2007).

\section{Seeds}

Moringa seed extracts exerts their protective effect by decreasing liver lipid peroxides. They contain antihypertensive compounds. Thiocarbamate and isothiocyanate glycosides have been isolated from the acetate phase of the ethanolic extract of Moringa pods (Faizi et al., 1998; Lalas and Tsaknis, 2002; Anwar et al., 2007).

\section{ANTIMICROBIAL SIGNIFICANCE OF M. OLEIFERA}

The medicinal properties of this plant have been attributed to a wide range of antimicrobial compounds present in its tissues (Kostova and Dinchev, 2005; Vieira et al., 2010). The cell walls of Gram-negative bacteria do not allow passage of many antibiotics, and thus act as a barrier to their action (Tortora et al., 2001). Accordingly, Moringa extracts tend to be more effective against Gram-positive than Gram-negative bacteria (Kudi et al., 1999; Ali et al., 2001; Palombo and Semple, 2001; Vieira et al., 2010). The widely reported antimicrobial action of this plant (Siddhuraju and Becker, 2003; Vaghasiya and Chanda, 2007; Mashiar et al., 2009; Walter et al., 2011) is mediated through the inhibition of enzyme activity or disruption of cell membranes (Silvestro et al., 2000; Suarez et al., 2003; Anwar et al., 2007). According to Cáceres et al. (1991), fresh leaf juice and aqueous seed extracts inhibit Pseudomonas aeruginosa and
Staphylococcus aureus growth. Folkard and Sutherland (2005) find that Moringa seeds destroy Salmonella typhi living in the human intestine. Oil in the seeds contains the antibiotic pterygospermin (Aney et al., 2009) that form a thin film over the walls of the intestines, thus protecting them from penetration by microorganisms (Caceres and Lopez, 1991; Cáceres et al., 1991; Nwosu and Okafor, 1995; Walter et al., 2011). The Moringa seeds also contain a gum like compound which is antityphoid in nature (Fuglie, 1999; Harristoy et al., 2005).

\section{Antimicrobial properties of different plant parts}

As mentioned earlier, all parts of $M$. oleifera plant exhibit antimicrobial properties (Arora and Onsare, 2014) (Table 1 ). The following paragraphs outline the antibacterial properties in the different parts of the tree.

\section{Pods}

The pod husks are found to have antibacterial properties effective against $S$. aureus, Staphylococcus epidermidis, Salmonella typhimurium, E. coli and Klebsiella pneumoniae. The major phytochemicals found in the pods are flavonoids, alkaloids, tannins, triterpenes, diterpenes and cardiac glycosides. Among these, the antimicrobial compounds are flavonoids and diterpenes (Arora and Onsare, 2014). According to Nantanchit (2006), purified extracts of capsules have been found to be effective against both Gram-positive and Gram-negative bacteria. The vegetable peels of $M$. oleifera have been observed to be active against Enterobacter aerogenes, $K$. pneumoniae, S. aureus, Staphylococcus subflava, Proteus mirabilis, Cryptococcus luteolus, Clostridium rubrum, S. typhimurium (Chanda et al., 2010).

\section{Roots}

In different civilizations including India, Vietnam and Pakistan, Moringa roots are held in high esteem owing to their antibacterial properties (Rao et al., 2001). In 1957, Das et al. reported that the antibiotic compound pterygospermin from Moringa roots were found to exhibit antifungal as well as antibacterial properties. After the 1950s, different researchers all over the world reported various antimicrobial components from the Moringa root. For example, Eilert et al. (1981) reported 4- $\alpha$-Lrhamnosyloxybenzyl isothiocyanate as a major antimicrobial constituent. In 2003, Nikkon et al. stated that the aglycone of deoxy-niazimicine (N-benzyl, S-ethyl thioformate) isolated from the chloroform fraction of an ethanol extract of the root bark was responsible for antibacterial and antifungal activities observed. The root bark was also reported by Dewangan et al. (2010) to show antibacterial activity against $S$. aureus, E. coli, Staphylococcus gallinarumm and $P$. aeruginosa. Raj et al. (2011) observed antimicrobial activity against $P$. aeruginosa, S. aureus, E. coli. 
Malays. J. Microbiol. Vol 15(3) 2019, pp. 244-259

DOI: http://dx.doi.org/10.21161/mjm.113117

Table 1: Antibacterial mode of action of major chemical classes of phytoconstituents and their subclasses.

\begin{tabular}{|c|c|c|c|c|}
\hline $\begin{array}{l}\text { Chemical } \\
\text { structural } \\
\text { classes }\end{array}$ & Major subclasses & Normal function & Antibacterial mode of action & References \\
\hline \multirow{3}{*}{ Phenolics } & $\begin{array}{l}\text { Simple phenols } \\
\text { Phenolic acids }\end{array}$ & $\begin{array}{l}\text { Protection against } \\
\text { oxidative stress }\end{array}$ & $\begin{array}{l}\text { Inhibition of ATP } \\
\text { production.Inhibition of enzymes } \\
\text { (urease, proline } \\
\text { dehydrogenase). Inhibition of } \\
\text { nucleic acid synthesis i.e. DNA } \\
\text { or RNA. }\end{array}$ & $\begin{array}{l}\text { Tholl, 2006; Simões et al., } \\
2009\end{array}$ \\
\hline & $\begin{array}{l}\text { Flavones } \\
\text { (apigenin, } \\
\text { luteolin) }\end{array}$ & $\begin{array}{l}\text { Antioxidants, anti- } \\
\text { inflammatory, and } \\
\text { anticancer activities }\end{array}$ & - & Bumke-Vogt et al., 2014 \\
\hline & $\begin{array}{l}\text { Flavonols } \\
\text { (quercetin, } \\
\text { kaempferol, } \\
\text { myricetin, } \\
\text { isorhamnetin) }\end{array}$ & $\begin{array}{l}\text { Attraction for pollinating } \\
\text { insects to flowers, } \\
\text { protection against UV } \\
\text { damage (flavonoids, } \\
\text { anthocyanins) }\end{array}$ & $\begin{array}{l}\text { Quercetin-increase in } \\
\text { permeability of inner bacterial } \\
\text { membrane, dissipation of } \\
\text { membrane potential, binding of } \\
\text { GyrB subunit of } E \text {. coli DNA } \\
\text { gyrase and inhibition of the } \\
\text { enzyme ATPase activity. }\end{array}$ & $\begin{array}{l}\text { Mirzoeva et al., 1997; } \\
\text { Plaper et al., 2003; Tholl, } \\
2006\end{array}$ \\
\hline Terpenoids & Terpenoids & $\begin{array}{l}\text { Plant-environment } \\
\text { interaction; also plant } \\
\text { fragnance, an essential oil }\end{array}$ & $\begin{array}{l}\text { Alteration of membrane } \\
\text { permeability, disruption of } \\
\text { cytoplasmic membrane. }\end{array}$ & $\begin{array}{l}\text { Cowan, 1999; Brehm- } \\
\text { Stecher and Johnson, } \\
\text { 2003; Simões et al., } 2008\end{array}$ \\
\hline Essential oils & Essential oils & Aroma and fragrance & $\begin{array}{l}\text { Alteration of ion transport } \\
\text { processes. Inhibition of } \\
\text { respiration. Disturbance of } \\
\text { membrane embedded protein. } \\
\text { Interference with membrane } \\
\text { expansion. Increase in } \\
\text { membrane fluidity and } \\
\text { permeability. }\end{array}$ & Simões et al., 2008 \\
\hline Alkaloids & Alkaloids & $\begin{array}{l}\text { Inhibition of multidrug } \\
\text { resistance }\end{array}$ & $\begin{array}{l}\text { Inhibition of efflux pumps, } \\
\text { interaction with bacterial } \\
\text { cytoplasmic membrane. }\end{array}$ & $\begin{array}{l}\text { Gibbons and Udo, 2000; } \\
\text { Simões et al., } 2008\end{array}$ \\
\hline Lectins & Lectins & $\begin{array}{l}\text { Pathogen invader. } \\
\text { Involvement in plant } \\
\text { physiology and } \\
\text { functionality }\end{array}$ & ch & $\begin{array}{l}\text { Cowan, 1999; Dorman and } \\
\text { Deans, 2000; Newman et } \\
\text { al., 2000; Stavri et al., } \\
\text { 2007; Simões et al., } 2009\end{array}$ \\
\hline Polypeptides & Peptides & $\begin{array}{l}\text { Signalling agents, working } \\
\text { as intracellular chemical } \\
\text { messengers }\end{array}$ & - & $\begin{array}{l}\text { Bergey et al., 1996; } \\
\text { Pearce et al., 2001 }\end{array}$ \\
\hline \multirow[b]{2}{*}{ Polyacetylenes } & Quinones & $\begin{array}{l}\text { Pathogen invader. } \\
\text { Involvement in plant } \\
\text { physiology and } \\
\text { functionality }\end{array}$ & - & $\begin{array}{l}\text { Cowan, 1999; Dorman and } \\
\text { Deans, 2000; Newman et } \\
\text { al., 2000; Stavri et al., } \\
\text { 2007; Simões et al., } 2009\end{array}$ \\
\hline & Tannins & $\begin{array}{l}\text { Structural constitutive } \\
\text { function, found in almost } \\
\text { every plant part (bark, } \\
\text { wood, leaves, fruits, } \\
\text { roots). Responsible for } \\
\text { astringent taste of wine or } \\
\text { unripe fruit. Components } \\
\text { of flower color and } \\
\text { autumn leaves }\end{array}$ & - & $\begin{array}{l}\text { Bergey et al., 1996; } \\
\text { Pearce et al., 2001 }\end{array}$ \\
\hline Miscellaneous & $\begin{array}{l}\text { Coumarins } \\
\text { Polyketides } \\
\text { Polyamines } \\
\text { Isothiocyanates } \\
\text { Sulfides } \\
\text { Thiosulfinates } \\
\text { Glycosides } \\
\text { Phenanthrenes } \\
\text { Stilbenes } \\
\end{array}$ & $\begin{array}{l}\text { Pathogen invader. } \\
\text { Involvement in plant } \\
\text { physiology and } \\
\text { functionality }\end{array}$ & - & $\begin{array}{l}\text { Cowan, 1999; Dorman and } \\
\text { Deans, 2000; Newman et } \\
\text { al., 2000; Stavri et al., } \\
\text { 2007; Simões et al., } 2009\end{array}$ \\
\hline
\end{tabular}




\section{Flowers}

Pterygosperminis also present in the flowers of $M$. oleifera. Thus, the flowers have antimicrobial properties which are effective against many microorganisms, including bacteria and fungi (Rao et al., 2001).

\section{Bark}

The stem of $M$. oleifera has been a drug of choice for treating urinary tract infection (UTI) as it is cheap and easily available (Chetia and Gogoi, 2011). It is reported to contain 4-hydroxymellin and octacosanoic acid (Faizi et al., 1994), two alkaloids (namely moringine and moringinie), vanillin, $\beta$-sitosterol, $\beta$-sitostenone, and phenolics (Kumbhar et al., 2012), procyanidin (Atawodi et al., 2010), and 4-(-I-rhamnopyranosyloxy)benzylglucosinolate (Bones and Rossiter, 1996; Maurya and Singh, 2014). It showed prominent effect against $E$. coli (MIC $64 \mu \mathrm{g} / \mathrm{mL}$ ), which is a major causative agent of UTI. Maurya and Singh, (2014) also concurred regarding its activity against $E$. coli (Chetia and Gogoi, 2011). Zaffer et al. (2014) found that the bark of M. oleifera has broad spectrum antibacterial properties effective against both Gram-positive and Gram-negative bacteria (Maurya and Singh, 2014). E. coli involved in UTI is killed by bark extract at MIC $64 \mathrm{\mu g} / \mathrm{mL}$ (Chetia and Gogoi, 2011; Maurya and Singh, 2014).

\section{Leaves}

The Moringa leaves contain protein that is reported to contain antimicrobial activity against $E$. coli, $K$. aerogenes, S. aureus and Bacillus subtilis (Dahot, 1998).

\section{Seeds}

Eilert et al. (1981) identified 4-alpha-rhamnosyloxy-benzyl isothiocyanate being an active antimicrobial agent in $M$. oleifera seed powder which helped in reducing Most Probable Number (MPN) and Standard Plate Count (SPC) at a dosage of $100-150 \mathrm{mg} / \mathrm{L}$ (Mangale et al., 2012). According to Padla et al. (2012), M. oleifera contains the antibacterial compound 4-( $\alpha$-L-rhamnosyloxy) benzyl isothiocyanate. It was effective against Mycobacterium phlei and $B$. subtilis at concentrations of $12.5 \mu \mathrm{g} / \mathrm{mL}$ and $17.5 \mu \mathrm{g} / \mathrm{mL}$ respectively (Eilert et al., 1981). The antimicrobial peptides in seeds of Moringa are discussed further below.

\section{Oil}

A study on the chemical composition of oil from leaves via GC and GCMS analysis found that hexacosane (13.9\%), pentacosane $(13.3 \%)$ and heptacosane $(11.4 \%)$ were the main constituents (Marrufo et al., 2013). UPLC-DAD analysis also detected the presence of the flavonoids quercetin $(126 \mu \mathrm{g} / \mathrm{g})$ and luteolin $(6.2 \mu \mathrm{g} / \mathrm{g})$. The bacteria $B$. cereus and $P$. aeruginosa were found to be sensitive to Moringa oil, with luteolin showing biological and pharmacological properties like antimicrobial, antiallergic, anticancer, antiplatelet and antioxidant characteristics.

\section{Antimicrobial peptide from seeds}

The crushed kernels of Moringa seeds are reported to possess antimicrobial water-soluble peptides (Suarez et al., 2005). These proteins have residues at their terminals, which can bind to any suspended particulate matter, including microorganisms, present in the medium. One such well-known antimicrobial peptide (AMP) is Flo. The positive charge of this cation enables it to interact with the negative charges present on the surface of microorganisms. This confers upon the peptide the role of the first line of defense against many pathogens. The amphiphilic structures of the AMP allow their incorporation into the cellular membrane, leading to transmembrane channel formation and the consequent leakage of cellular components out of the cell. Depolarization of bacterial membrane follows, resulting in uneven distribution of lipids between cell membrane layers, leading eventually to intracellular damage (Zhang et al., 2001; Suarez et al., 2005). Cell death has been hypothesized in the following ways (Suarez et al., 2005).

Barrel Stave Model: By formation of pores by amphipatic helices of the peptide in the lipid bilayer, either in the lipid core region or aqueous environment within the pore (Boheim, 1974; Ehrenstein and Lecar, 1977; He et al., 1995)

Aggregate Channel Model: By formation of pores constituted by peptide and phospholipid heads from bent membrane (Matsuzaki et al., 1996; Oren and Shai, 1998).

Carpet Model: By a more general disorganization of the membrane hydrophobic and hydrophilic layers, leading to their disruption (Pouny et al., 1992; He et al., 1996; Bechinger, 1999; Heller et al., 2000).

The strong antimicrobial activity of the Moringa AMP is under investigation in many laboratories. Improvement to the AMP has been achieved either by mutating the primary sequence, for instance, to augment its amphiphilic character (Dathe et al., 1996; Friedrich et al., 2000; Dathe et al., 2001; Tachi et al., 2002; Farnaud et al., 2004), or by multimerizing the active sequence (Azuma et al., 1999; Lee et al., 2002; Tam et al., 2002).

\section{Recommended dosage}

The recommended doses of different parts of $M$. oleifera plant are: intact form of seed: 5-10 grams, root bark: $2-5$ grams, leaf (aqueous juice): $10-20 \mathrm{ml}$, powder of seed, root, bark, leaf, fruit and flower: 1-3 grams. (API; Mishra et al., 2011). 


\section{PHYTOCHEMISTRY OF M. OLEIFERA}

In order to understand the exact mechanism of a bioactive compound from $M$. oleifera against microorganisms, it is necessary to have some insights into the phytochemistry of the plant. The phytochemical profile for $M$. oleifera plants includes alkaloids, saponin, glycoside, flavanoids, tannins and terpenoids. Various chemical compounds, including tannins, saponins, flavonoids and steroids, are found in its leaves, seeds and flowers. Among the compounds present in extracts of Moringa that are responsible for the plant's antimicrobial activity are tannins (Scalbert, 1991), glycosides (Aboaba and Efuwape, 2001), saponins (Hostettman and Nakanishi, 1979), terpenoids and flavonoids (Leven et al., 1979), and alkaloids (Karou et al., 2005; Gami and Parabia, 2011). The phytochemicals found in seeds have been found to be effective against $K$. pneumoniae, $S$. aureus and Streptococcus. The agent present in the flower is effective against $E$. coli, K. pneumoniae and $P$. mirabilis. The leaf compounds are effective against $E$. coli, K. pneumoniae, Enterobacter, $P$. aeruginosa and $S$. aureus (Nepolean et al., 2009). The details of phytochemical constituents in $M$. oleifera are given in Table 2.

\section{Antibacterial mode of action of different phytoconstituents}

The antimicrobial modes of action of different constituents from $M$. oleifera are given below (Table 2) while Figure 2 shows a graphical summary of mode of action of different parts of the $M$. oleifera plant.

\section{Essential Oils}

In the plant kingdom, many species produce essential oils, for example thymol, terpenoids, carvacol etc. that are responsible for the characteristic flavor and aroma of the plant. Although their exact mechanisms of action are not known, they are considered to be involved in the disruption of bacterial membranes through formation of lipophilic products that could increase membrane permeability and membrane fluidity, alter the ion transport processes, inhibit the electron transport chain, interfere with membrane-embedded proteins, alter membrane size, etc. (Mendoza et al., 1997; Griffin et al., 1999; Simões et al., 2009). Any of the said mechanisms or a combination of them could induce the deaths of Gram-positive and Gram-negative bacteria (Simões et al., 2009).

\section{Alkaloids}

Alkaloids are known to inhibit efflux mechanism by intercalating with DNA. Essentially, alkaloids can disrupt bacterial cytoplasmic membrane, resulting in antibacterial action (Jennings and Ridler, 1983; Khan et al., 2006; Simões et al., 2009). Khan et al. (2006) reported alkaloids as antimicrobial agent against $S$. aureus.

\section{Phenols and Phenolic Acids}

Phenol and phenolic compounds inhibit enzymes like polyphenol oxidase by binding covalently to functional residues of proteins including sulfhydral and primary amino groups, resulting in disruption of energy production (Mason and Wasserman, 1987; Simões et al., 2009). The inhibition of enzymes like urease or proline dehydrogenase by phenolics has been reported (Simões et al., 2009). The inhibition of proline dehydrogenase results in the disruption of energy production at the plasma membrane of Gram-negative bacteria such as Helicobacter pylori (Li et al., 2005; Simões et al., 2009).

Plants are hosts to many antioxidants that include phenolics which act as free radical terminators or metal chelators (Shahidi et al., 1992). In plant seeds, they are commonly present in bound form (Arranz et al., 2009), cross linking with the cell wall through ester or ether linkages involving their hydroxyl and carboxyl groups (Yu et al., 2001). These bound phenolics are released when seeds are subjected to treatments with enzymes, acids or alkalis (Durkee and Thivierge, 1975; Krygier et al., 1982; Dvořáková et al., 2008). According to Negi, (2012), phenolic compounds that display antibacterial potential include quercetin, cinnamic acid, protocatechuic acid, caffeic acid, vanillin, ferulic acid, p-coumaric acid, catechin, epicatechin, and gallic acid (Singh et al., 2013).

\section{Flavonoids}

Flavonoids that include various polyphenols are known to inhibit the synthesis of the nucleic acids of Gram-positive and Gram-negative bacteria. Flavonoids contain a B-ring which plays the role of an intercalating agent by creating hydrogen bond in stacks of nucleic acid. In this manner, flavonoids play a significant role in inhibiting the synthesis of DNA or RNA (Mori et al., 1987; Mirzoeva et al., 1997; Cushnie and Lamb, 2005; Simões et al., 2009).

Crude extracts of flavonoids from selected plant species and tissue calli have been tested for their antimicrobial activity against the Gram-positive bacteria $B$. subtilis, $S$. aureus, the Gram-negative bacteria $E$. coli, $K$. pneumoniae and the fungal pathogen $C$. albicans. Flavonoids extracted especially from tissue calli show high antimicrobial activity against microorganisms because of the higher concentrations of flavonoids in such material (Talreja, 2010; Talreja et al., 2012; Onsare and Arora, 2014).

\section{Antibacterial activity in different extracts}

The presence of secondary metabolites in plants confers the following advantages to their hosts: they protect against biotic or abiotics stresses, they serve as defense mechanisms by virtue of their repellent properties, and they maintain tissue structural integrity. Secondary metabolites of plants, including phenolic compounds, alkaloids, flavonoids, terpenoids, can be extracted in organic or aqueous solvents (Paiva et al., 2010). The extracts are categorized on the basis of their polarity: 
1. Polar solvents: e.g. organic acids.

2. Solvents of intermediate polarity e.g. methanol, ethanol, acetone, dichloromethane.

3. Low polarity solvents e.g. hexane, chloroform.

Many studies have been undertaken to investigate medicinal plants in order to validate their ethnopharmacological claims. The extract of the same plant part in solvents of different polarities may exhibit different biological properties (Tepe et al., 2005; Paiva et al., 2010). Almost all the plant parts of Moringa can be used for organic solvent extraction. Organic extracts may have antibacterial property against only Gram-negative bacteria or Gram-positive bacteria, or both. As mentioned earlier, Gram-negative bacteria have an outer membrane containing lipopolysaccharides which makes it impermeable to lipophilic solutes, while the presence of porins act as a selective barrier to hydrophilic solutes with a cut off value of $600 \mathrm{Da}$. Solutes greater in size than 600 Da cannot pass through porins (Paiva et al., 2010). On the other hand, the presence of an outer peptidoglycan layer on Gram-positive bacteria makes it more susceptible to solutes as it is not considered an effective barrier (Arias et al., 2004; Paiva et al., 2010). The solvents used for extraction can be hexane, acetone, methanol, ethanol, etc. According to previous literature (Jabeen et al., 2008 Khesorn, 2009), ethanolic, methanolic, and dichloromethane extracts show the highest antimicrobial activities against various Gram-negative and Grampositive bacteria.

\section{Acetone extract}

The acetone extract of Moringa contains various phytochemicals, including phenolics, flavonoids, tannins, glycosides (Korithu et al., 2011), alkaloids, carbohydrates, proteins, amino acids, saponins and triterpenoids (Gami and Parabia, 2011). These agents have been shown to be effective against $S$. typhii, $S$. aureus, E. coli and $B$. subtilis (Korithu et al., 2011). Masika et al. (2012) reported the antimicrobial effect of leaf acetone extract at $5 \mathrm{mg} / \mathrm{ml}$ against both Gram-negative and Gram-positive bacteria, including E. coli, Enterobacter cloacae, P. vulgaris, S. aureus and Micrococcus kristinae. M. oleifera acetone extract was bactericidal on $E$. coli and $M$. kristinae, while it was bacteriostatic on S. aureus, E. cloacae and Proteus vulgaris. Although, the minimal bactericidal concentration (MBC) value for the $M$. oleifera acetone extract against $M$. kristinae was higher $(1.0 \mathrm{mg} / \mathrm{mL})$ than its minimal inhibitory concentration (MIC) value of $0.5 \mathrm{mg} / \mathrm{mL}$, it is interesting to note that the MIC and MBC values (5 $\mathrm{mg} / \mathrm{mL}$ ) against the inhibited bacteria were the same (Masika et al., 2012).

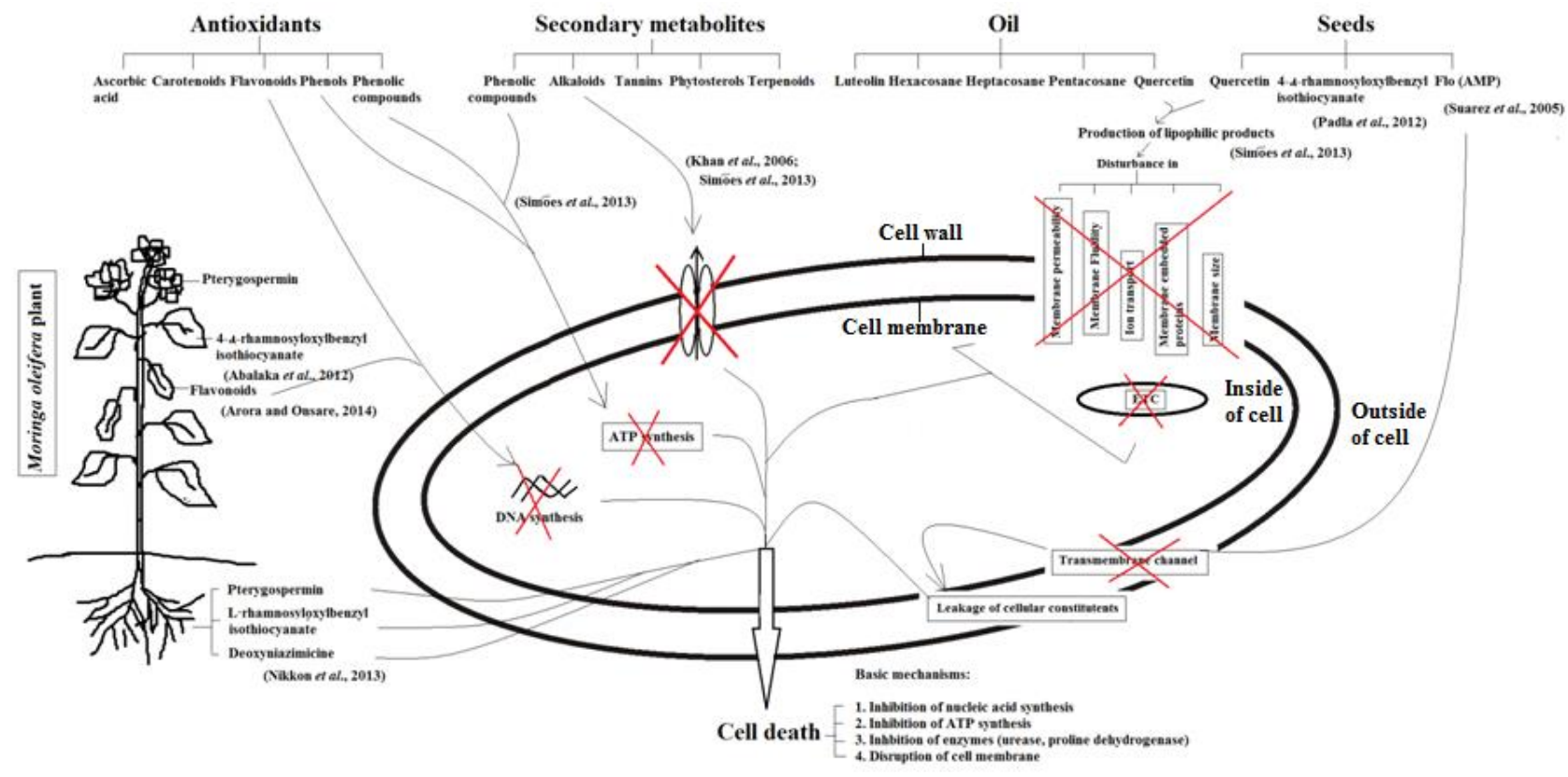

Figure 2: Overall summary of mode of action of different parts of $M$. oleifera plant. 
Malays. J. Microbiol. Vol 15(3) 2019, pp. 244-259

DOI: http://dx.doi.org/10.21161/mjm.113117

Table 2: Antibacterial property of phytoconstituents present in M. oleifera plant parts.

\begin{tabular}{|c|c|c|c|c|}
\hline $\begin{array}{l}\text { Plant } \\
\text { parts }\end{array}$ & Constituents & $\begin{array}{l}\text { Antimicrobial } \\
\text { property }\end{array}$ & $\begin{array}{l}\text { Microorganisms against which it } \\
\text { is active }\end{array}$ & References \\
\hline \multirow{3}{*}{$\begin{array}{l}\text { Whole } \\
\text { plant }\end{array}$} & Rhamnose & - & - & \multirow{3}{*}{$\begin{array}{l}\text { Fahey et al., } \\
\text { 2001; Bennet et } \\
\text { al., } 2003\end{array}$} \\
\hline & Glucosinolates & - & - & \\
\hline & Isothiocyanates & Yes & Both Gram + \& - & \\
\hline \multirow{8}{*}{$\begin{array}{l}\text { Stem } \\
\text { bark }\end{array}$} & Alkaloid & Yes & Both Gram + \& - & \multirow{8}{*}{$\begin{array}{l}\text { Kerharo, 1969; } \\
\text { Faizi et al., 1994a }\end{array}$} \\
\hline & Moringine & - & - & \\
\hline & Moringinie & - & - & \\
\hline & Vanillin & - & - & \\
\hline & $\beta$-sitosterol & - & - & \\
\hline & $\beta$-sitostenone & - & - & \\
\hline & 4-hydroxymellin & - & - & \\
\hline & Ocatcosanoic acid & - & - & \\
\hline \multirow{6}{*}{$\begin{array}{l}\text { Whole } \\
\text { gum } \\
\text { exudate }\end{array}$} & L-arabinose & - & - & \multirow{6}{*}{$\begin{array}{l}\text { Bhattacharya et } \\
\text { al., } 1982\end{array}$} \\
\hline & L-galactose & - & - & \\
\hline & L-glucuronic acid & - & - & \\
\hline & L-rhamnose & - & - & \\
\hline & L-mannose & - & - & \\
\hline & L-xylose & - & - & \\
\hline \multirow{3}{*}{$\begin{array}{l}\text { Degraded } \\
\text { gum } \\
\text { exudate }\end{array}$} & L-galactose & - & - & \multirow{3}{*}{$\begin{array}{l}\text { Bhattacharya et } \\
\text { al., } 1982\end{array}$} \\
\hline & L-glucuronic acid & - & - & \\
\hline & L-mannose & - & - & \\
\hline \multirow{12}{*}{ Flowers } & Nine amino acids Sucrose & - & - & \multirow{12}{*}{$\begin{array}{l}\text { Faizi et al., } \\
\text { 1994a; } \\
\text { Siddhuraju and } \\
\text { Becker, } 2003\end{array}$} \\
\hline & D-glucose & - & - & \\
\hline & Traces of alkaloids & - & - & \\
\hline & Wax & Yes & Both Gram + \& - & \\
\hline & Quercetin & - & - & \\
\hline & Kaempferate & Yes & Both Gram + \& - & \\
\hline & Flavonoid pigments & - & - & \\
\hline & Alkaloids & Yes & Both Gram + \& - & \\
\hline & Kaempheorl & - & - & \\
\hline & Rhamnetin & - & - & \\
\hline & Isoquercitrin & - & - & \\
\hline & Kaempferitrin & - & - & \\
\hline \multirow{2}{*}{ Pods } & Thiocarbamate & - & - & \multirow{2}{*}{ Faizi et al., 1998} \\
\hline & Isothiocyanate glycoside & - & - & \\
\hline Fruit & Cytokinin & - & - & Nagar et al., 1982 \\
\hline \multirow{4}{*}{ Leaves } & Ascorbic acid & - & - & \multirow{4}{*}{$\begin{array}{l}\text { Anwar et al., } \\
\text { 2005; Makkar and } \\
\text { Becker, } 1996\end{array}$} \\
\hline & Flavonoid & - & - & \\
\hline & Phenolics & Yes & Both Gram + \& - & \\
\hline & Carotenoids & - & - & \\
\hline \multirow{4}{*}{ Roots } & Pterygospermin & Yes & Both Gram + \& - & \multirow{4}{*}{$\begin{array}{l}\text { Das et al., 1957; } \\
\text { Eilert et al., 1981; } \\
\text { Rao et al., 2001; } \\
\text { Dewangan et al., } \\
2010\end{array}$} \\
\hline & 4- $\alpha-L$-rhamnosyloxybenzyl isothiocyanate & Yes & Both Gram + \& - & \\
\hline & Aglycone of deoxy-niazimicine (N-benzyl, S-ethyl & Yes & Both Gram + \& - & \\
\hline & thioformate) & & & \\
\hline \multirow{7}{*}{ Seed } & O-ethyl-4-(a-L-rhamnosyloxy) benzyl carbamate & - & - & Guevara et al., \\
\hline & & Yes & Both Gram + \& & 1999; Anwar et \\
\hline & $\begin{array}{l}\text { Niazimicin } \\
\text { 3-o-(6'-O-oleyl- } \beta \text {-D-glucopyranosyl)- } \beta \text {-sitosterol }\end{array}$ & & _ & al., 2007 \\
\hline & $\beta$-sitosterol-3-o- $\beta$-D-glucopyranoside & & - & \\
\hline & Niazirin & - & - & \\
\hline & $\beta$-sitosterol & $\ldots$ & - & \\
\hline & Glycerol-1-(9-octadecanoate) & - & - & \\
\hline & Campesterol, & - & - & Tsaknis et al., \\
\hline & Stigmasterol, & - & - & 1999; Lalas and \\
\hline & $\beta$-sitosterol, & - & - & Tsaknis, 2002; \\
\hline & $\Delta^{5}$-avenasterol, & - & - & Anwar and \\
\hline Oil (seed) & Clerosterol, & - & - & Bhanger, 2003; \\
\hline & 24-methylene cholesterol, & - & - & Anwar et al., \\
\hline & $\Delta^{7}$-campestanol, & - & - & 2005 \\
\hline & Stigmastanol, & - & - & \\
\hline & 28-isoavenasterol & - & - & \\
\hline
\end{tabular}




\section{Ethanolic Extract}

Bukar et al. (2010) reported that $M$. oleifera leaf ethanolic extract had the broadest spectrum of activity on the test bacteria, a finding that was in agreement with Doughari et al. (2007). The ethanolic extract of $M$. oelifera was reported to be effective against $B$. subtilis and $S$. aureus, $E$. coli and $K$. pneumoniae (Talreja, 2010). Peixoto et al. (2011) found it effective against $S$. aureus, $V$. parahaemolyticus, E. feacalis and $A$. caviae. Doughari et al. (2007) reported an ethanolic extract of the plant at 100 $\mathrm{mg} / \mathrm{ml}$ demonstrated the highest activity, while the aqueous extract showed the least activity. Renitta et al. (2009) reported highest antimicrobial activity from the ethanolic extract of leaves, seeds and flowers of $M$. oleifera against microorganisms like $E$. coli, $K$. pneumoniae, Enterobacter spp., $P$. mirabilis, $P$. aeroginosa, S. typhi A, S. aureus, Streptococcus spp. and C. albicans (Kalpana et al., 2013). One study showed that whereas the seed aqueous extract was not effective against Gram-negative bacteria ( $E$. coli, Shigella flexneri and $S$. typhi), the seed ethanolic extract showed zones of inhibition against the same (Cáceres et al., 1991; Jamil et al., 2007; Lar et al., 2011; Mishra et al., 2011; Saadabi and Abu, 2011; Farooq et al., 2012). Ethanol based extracts were also effective against $S$. aureus and Vibrio cholera (Vieira et al., 2010) and against E. coli, S. flexneri, and S. typhi (Lar et al., 2011).

\section{Ethyl acetate extract}

In one study, an ethyl acetate extract of Moringa leaf recorded the highest antimicrobial activity against four microorganisms namely, $S$. epidermidis, $S$. aureus, $P$. aeruginosa and Bacillus cereus, respectively (Abdallah, 2016).

\section{Butanol extract}

In the same study, a butanol Moringa leaf extract was active only against $S$. epidermidis and $S$. aureus (Abdallah, 2016).

\section{Aqueous extract}

Abalaka et al. (2012) found that the MIC of an aqueous leaf extract on E. coli and S. typhi were $1.667 \mathrm{mg} / \mathrm{ml}$ and $0.417 \mathrm{mg} / \mathrm{ml}$ respectively, but no MIC was reported for of the extract on P. aeruginosa. Mehta and Agrawal, (2008) also reported antimicrobial activity of an aqueous extract of seeds against $E$. coli, $S$. aureus and $P$. aeruginosa. The water-based extract was similarly found to be effective against S. aureus and V. cholera (Vieira et al., 2010). According to Abdallah, (2016) an aqueous leaf extract was active only against $S$. epidermidis. Unlike leaves, the aqueous extracts of seeds did not show any activity (Cáceres et al., 1991; Jamil et al., 2007; Jabeen et al., 2008; Lar et al., 2011; Mishra et al., 2011; Saadabi and Abu, 2011; Farooq et al., 2012). Another Morinaga species, M. peregrine, showed activity in its aqueous seed extracts and seed oil against E. coli, C. albicans, $S$. aureus, S. epidermidis, P. aeruginosa (Spiliotis et al., 1997; Lalas et al., 2012).

\section{Hexane extract}

Antibacterial activity of $M$. oleifera seeds in a hexane extract was reported against $S$. typhi, V. cholera and $E$. coli (Walter et al., 2011).

\section{Chloroform extract}

Nikkon et al. (2003) isolated the aglycon of deoxyniazimicine ( $\mathrm{N}$-benzyl,S-ethyl thioformate) from $M$. oleifera crude chloroform extract. It exhibited antimicrobial activity against $S$. aureus, Shigella dysenteriae, Shigella boydii, $S$. typhi and $P$. aeruginosa. The antibacterial effect of the chloroform extract was also reported against $S$. aureus (Abdallah, 2016). The MICs of the chloroform leaf extract on E. coli, S. typhi and $P$. aeruginosa were $1.667 \mathrm{mg} / \mathrm{mL}$, $0.417 \mathrm{mg} / \mathrm{mL}$ and $0.417 \mathrm{mg} / \mathrm{mL}$, respectively (Abalaka et al., 2012).

\section{Methanol extract}

A methanol extract of Moringa leaves was found effective against a broad range of microorganisms, including $K$. pneumoniae, $P$. aeruginosa, Enterobacter. aerogens, Salmonella typhi, Salmonella paratyphi A, S. aureus, Micrococcus luteus and B. Subtilis (Gami and Parabia, 2011). The methanolic extract of dried leaf of $M$. oleifera was found to possess potent phytochemicals with high inhibitory activities on bacteria of UTI origin (Okiki et al., 2015).

\section{Phytochemicals and biofilms}

When bacterial cells start to grow on a solid surface, the colony may take the form of film that is known as a biofilm (Simões et al., 2009). The plant-microbe interaction can be exploited for the production of phytochemicals that can interfere with biofilm formation (Costerton et al., 1987; Ramey et al., 2004; Jain et al., 2007; Simões et al., 2009). Biofilm formation involves the attachment of bacterial cells by extracellular appendages and hydrophobicity of cell surface. If this step is disturbed, then biofilm formation cannot take place. This initial attachment can be disturbed by flavonoids obtained from $M$. oleifera seed coat (Cushnie and Lamb, 2005). This step is concentration and exposure time dependent (Simões et al., 2008).

\section{Antibacterial mode of action}

The presence of the lipopolysaccharide membrane in Gram-negative bacteria makes it impermeable to exogenous molecules (Nikaido and Vaara, 1985; Gami and Parabia, 2011). The significance of the cell membrane is already known. It is involved in various processes like uptake and transport of solute molecules, cell signaling, metabolism regulation, energy transducing 
processes, and maintenance of osmotic pressure (Sikkema et al., 1995). In Gram-positive bacteria, the cell membrane has low lipid content and is high in lipoteichoic acids. When an antibacterial agent enters the cell, imbalance of ions $\left(\mathrm{K}^{+}\right.$and $\left.\mathrm{H}^{+}\right)$occurs, resulting in disturbance of metabolism which leads to protein and enzyme denaturation and, eventually, cell death According to Singh et al. (2013), phenolic compounds disturb the enzymatic machinery of the cell, thereby inducing an antimicrobial effect. In Gram-negative bacteria, the presence of the outer lipopolysaccharide membrane makes entry of exogenous compounds difficult. If antibiotic compounds gain entry, cell membrane disruption takes place due to interference in ATP generation from dextrose (Gill and Holley, 2004). Cushnie and Lamb, (2005) reported that phenolic compounds like quercetin and luteolin which are found in Moringa extracts interfere with the bacterial DNA gyrase activity.

\section{CONCLUSIONS}

A serious threat of multi-drug resistance has arisen this century. In such a scenario, natural remedies are increasingly under investigation to validate their reputed pharmaceutical properties in the quest for new drugs. $M$. oleifera, despite being regarded by many as a miracle tree, has not been well researched or validated for its many potential medicinal applications. Reports on its antimicrobial properties, for example, are few and dispersed in different publications. This review is, therefore, an effort to collect all the antimicrobial information related to the plant's parts, extracts and phytochemistry of $M$. oleifera. In summary, it can be said that all parts of the Moringa plant that are extracted in any solvent exhibit antimicrobial properties against Grampositive and Gram-negative bacteria. The Moringa plant offers natural and safe protection against a broad spectrum of pathogens.

CONFLICT OF INTEREST: The authors declare no conflict of interest.

\section{REFERENCES}

Abalaka, M. E., Daniyan, S. Y., Oyeleke, S. B. and Adeyemo, S. O. (2012). The antibacterial evaluation of Moringa oleifera leaf extracts on selected bacterial pathogens. Journal of Microbiology Research 2(2), 14.

Abdallah, E. M. (2016). Antibacterial properties of leaf extracts of Moringa oleifera Lam. growing in Sudan. Journal of Advances in Medical and Pharmaceutical Sciences 5(1), 1-5.

Aboaba, O. O. and Efuwape, B. M. (2001). Antibacterial properties of some Nigerian spices. Biology Research Communications 13, 183-188.

Ali, N. A. A., Jülich, W. D., Kusnick, C. and Lindequist, U. (2001). Screening of Yemeni medicinal plants for antibacterial and cytotoxic activities. Journal of Ethnopharmacology 74, 173-179.
Anwar, F. and Bhanger, M. I. (2003). Analytical characterization of Moringa oleifera seed oil grown in temperate regions of Pakistan. Journal of Agricultural and Food Chemistry 51, 6558-6563.

Anwar F., Ashraf, M., and Bhanger, M. I. (2005). Interprovenance variation in the composition of Moringa oleifera oilseeds from Pakistan. Journal of American Oil Chemists' Society 82, 45-51.

Anwar F., Latif, S., Ashraf, M. and Gilani, A. H. (2007). Moringa oleifera: a food plant with multiple medicinal uses. Pytotherapy Research 21, 17-25.

Aney J., Rashmi, T., Maushumi, K. and Kiran, B. (2009). Pharmacological and pharmaceutical potential of Moringa oleifera: A review. Journal of Pharmacy Reseacrh 2(9), 1424-1426.

API - The Ayurvedic Pharmacopoeia of India, Part I. Government of India. Ministry of Health and Family Welfare, Department of Ayush, 2, 163-165.

Arias M. E., Gomez, J. D., Cudmani, N. M., Vattuone, M. A. and Isla, M. I. (2004). Antibacterial activity of ethanolic and aqueous extracts of Acacia aroma Gill. ex Hook et Arn. Life Sciences, 75, 191-202.

Arora, D. S., Onsare, J. G. and Kaur, H. (2013). Bioprospecting of Moringa (Morinagaceae): microbiological perspective. Journal of Pharmacognosy and Phytochemistry 1(6), 193-215.

Arora, D. S. and Onsare, J. G. (2014). In vitro antimicrobial evaluation and phytoconstituents of Moringa oleifera pod husks. Industrial Crops and Products 52, 125-135.

Arranz S., Saura-Calixto, F., Shaha, S. and Kronn, P. A. (2009). High contents of nonextractable polyphenols in fruits suggest that polyphenol contents of plant foods have been underestimated. Journal of Agricultural and Food Chemistry 57, 7298-7303.

Atawodi S. E., Atawodi, J. C., Idakwo, G. A., Pfundstein, B., Huabner, R., Wurtele, G., Bartsch, H. and Owen, R. W. (2010). Evaluation of the polyphenol content and antioxidant properties of methanol extracts of the leaves, stem, and root barks of Moringa oleifera Lam. Journal of Medicinal Food 13(3), 710-716.

Azuma, M., Kojima, T., Yokoyama, I., Tajiri, H., Yoshikawa, K., Saga, S. and Del-Caprio, C. A. (1999). Antibacterial activity of multiple antigen peptides homologous to a loop region in human lactoferrin. Journal of Peptide Research 54, 237-241.

Balandrin, M. F., Klocke, J. A., Wurtele, E. S. and Bollinge, W. H. (1985). Natural plant chemicals: sources of industrial and medicinal materials. Science 228, 1154-1160.

Bechinger, B. (1999). The structure, dynamics and orientation of antimicrobial peptides in membranes by multidimensional solid-state NMR spectroscopy. Biochimica et Biophysica Acta 1462, 157-183.

Bennet, R. N., Mellon, F. A., Foidl, N., Pratt, J. H., Dupont, M. S., Perkins, L. and Kroon, P. A. (2003). Profiling glucosinolates and phenolics in vegetative and reproductive tissues of the multi-purpose trees Moringa oleifera (horseradish tree) and Moringa 
stenopetala L. Journal of Agricultural and Food Chemistry 51, 3546-3553.

Bergey, D. R., Howe, G. A. and Ryan, C. A. (1996). Polypeptide signaling for plant defensive genes exhibits analogies to defense signaling in animals. Proceedings of the National Academy of Sciences of the United States of America 93(22), 12053-12058.

Bhatnagar, S. S., Santapau, H., Desai, J. D. H., Yellore, S. and Rao, T. N. S. (1961). Biological activity of Indian medicinal plants. I. Antibacterial, antitubercular and antifungal action. The Indian Journal of Medical Research, 49, 799-805.

Bhattacharya, S. B., Das, A. K. and Banerji, N. (1982). Chemical investigations on the gum exudates from Sonja (Moringa oleifera). Carbohydrate Research 102, 253-262.

Boheim, G. (1974). Statistical analysis of alamethicin channels in black lipid membranes. Journal of Membrane Biology 19, 277-303.

Bones, A. M. and Rossiter, J. T. (1996). The pyrosinaseglucosinolate system, its organisation and biochemistry. Physiologia Plantarum 97(1), 194-208.

Booth, F. E. M. and Wickens, G. E. (1988). Non- timber uses of selected arid zone trees and shrubs in Africa (1988). FAO Conservation Guide 19, Rome, Food and Agriculture Organization, 1988, 176. The Plant List (2010). (Published on the internet; version 1; http://www.theplantlist.org/-accessed $1^{\text {st }}$ January, 2017).

Brehm-Stecher, B. F. and Johnson, E. A. (2003). Sensitization of Staphylococcus aureus and Escherichia coli to antibiotics by the sesquiterpenoids Nerolidon, Farnesol, Bisabolol, and Apritone. Antimicrobial Agents and Chemotherapy 47(10), 33573360.

Bukar A., Uba, A. and Oyeyi, T. I. (2010). Antimicrobial profile of Moringa oleifera Lam. extracts against some food borne microorganisms. Bayero Journal of Pure and Applied Sciences 3(1), 43-48.

Bumke-Vogt, C., Osterhoff, M. A., Borchert, A., Guzman-Perez, V., Sarem Z., Birkenfeld, A. L., Bähr, V. and Pfeiffer, A. F. H. (2014). The flavones apigenin and luteolin induce FOXO1 translocation but inhibit gluconeogenic gene expression in human cells. PLOS ONE 9(8), 1-16.

Caceres, A. and Lopez, S. (1991). Pharmacological properties of Moringa oleifera. 3: Effects of seed extract in the treatment of experimental pyodermia. Fitoterapia 62, 449-450.

Cáceres, A., Cabrera, O., Morales, O., Mollinedo, P. and Mendia, P. (1991). Pharmacological properties of Moringa oleifera. 1: Preliminary screening for antimicrobial activity. Journal of Ethnopharmacology 33, 213-216.

Chanda, S., Baravalia, Y., Kaneria, M. and Rakholiya, K. (2010). Fruits and vegetable peels - strong natura source of antimicrobics; current research, technology and education topics. In: Current Research, Technology and Education Topics in Applied
Microbiology and Microbial Biotechnology. MéndezVilas, A. (ed.). Formatex. pp. 444-450.

Chetia, B. and Gogoi, S. (2011). Antibacterial activity of the methanolic extract of stem bark of Spondias pinnata, Moringa oleifera and Alstonia scholaris. Asian Journal of Traditional Medicine 6(4), 163-167.

Costerton, J. W., Cheng, K. J., Geesey, G. G., Ladd, T. I., Nickel, J. C., Dasgupta, M. and Marrie, T. J. (1987). Bacterial biofilms in nature and disease. Annual Review of Microbiology 41, 435-464.

Cowan, M. M. (1999). Plant products as antimicrobial agents. Clinical Microbiology Reviews 12(4), 564-582.

Croteau, R., Kutchan, T. M. and Lewis, N. G. (2000). Natural products (secondary metabolites). In: Biochemistry and Molecular Biology of Plants (Buchanan, B., Gruissem, W., Jones, R., (eds.). Rockville, MD, American Society of Plant Physiology. pp. 1250-1318.

Cushnie, T. P. T. and Lamb, A. J. (2005). Antimicrobial activity of flavonoids. International Journal of Antimicrobial Agents 5, 343-356.

Dahot, M. U. (1998). Antimicrobial activity of small protein of Moringa oleifera leaves. Journal of Islamic Academy of Sciences 11(1), 27-32.

Das, B. R., Kurup, P. A., Rao, P. L. and NarasimhaRao, P. L. (1957). Antibiotic principle from Moringa pterygosperma. VII. Antibacterial activity and chemical structure of compounds related to pterygospermin. Indian Journal of Medicinal Research 45, 191-196.

Dathe, M., Schumann, M., Wieprecht, T., Winkler, A., Beyermann, M., Krause, E., Matsuzaki, K., Murase, O. and Bienert, M. (1996). Peptide helicity and membrane surface charge modulate the balance of electrostatic and hydrophobic interactions with lipid bilayers and biological membranes. Biochemistry 35, 12612-12622.

Dathe M., Nikolenko, H., Meyer, J., Beyermann, M. and Bienert, M. (2001). Optimization of the antimicrobial activity of magainin peptides by modification of charge. FEBS Letters 501, 146-150.

Dewangan, G., Koley, K. M., Vadlamudi, V. P., Mishra, A., Poddar, A. and Hirpurkar, S. D. (2010). Antibacterial activity of Moringa oleifera (drumstick) root bark. Journal of Chemical and Pharmaceutical Research 2(6), 424-428.

Dillard, C. J. and German, J. B. (2000). Phytochemicals: nutraceuticals and human health. A review. Journal of the Science of Food and Agriculture 80, 1744-1756.

Dorman, H. J. D. and Deans, S. G. (2000). Antimicrobial agents from plants: antibacterial activity of plant volatile oils. Journal of Applied Microbiology 88(2), 308-316.

Doughari, J. H., Pukuma, M. S. and De, N. (2007). Antibacterial effects of Balanites aegyptiaca L. Drel. and Moringa oleifera Lam. on Salmonella typhi. African Journal of Biotechnology 6(19), 2212-2215.

Durkee, A. B. and Thivierge, A. P. (1975). Bound phenolic acids in Brassica and Sinapis oilseeds. Journal of Food Science 40, 820-822. 
Dvořáková, M., Guido, L. F., Dostalek, P., Skulilová, Z., Moneira, M. M. and Barros, A. A. (2008). Antioxidant properties of free, soluble ester and insoluble compounds in different barley varieties and corresponding malts. Journal of the Institute of Brewing 114, 27-33.

D'souza, J. and Kulkarni, A. R. (1993). Comparative studies on nutritive values of tender foliage of seedlings and mature plants of Moringa oleifera Lam. Journal of Economic and Taxonomic Botany 17, 479485.

Ehrenstein, G. and Lecar, H. Q. (1977). Electrically gated ionic channels in lipid bilayers. Quarterly Reviews of Biophysics 10(1), 1-34.

Eilert, U., Wolters, B. and Nadrtedt, A. (1981). The antibiotic principle of seeds of Moringa oleifera and Moringa stenopetala. Planta Medica 42, 55-61.

Estrella, M. C. P., Mantaring, J. B. V. and David, G. Z. (2000). A double-blind randomized control trial on the use of malunggay (Moringa oleifera) for augmentation of the volume of breastmilk among non-nursing mothers of preterm infants. Philippines Journal of Pediatrics 49, 3-6.

Fahey, J. W., Zalcmann, A. T. and Talalay, P. (2001). The chemical diversity and distribution of glucosinolates and isothiocyanates among plants. Phytochemistry 56(1), 5-51.

Faizi, S., Siddiqui, B. S., Saleem, R., Siddiqui, S., Aftab, K. and Gilani, A. H. (1994). Isolation and structure elucidation of newnitrile and mustard oil glycosides from Moringa oleifera and their effect on blood pressure. Journal of Natural Products 57(9), 1256-1261.

Faizi, S., Siddiqui, B. S., Saleem, R., Aftab, K., Shaheen, F. and Gilani, A. H. (1998). Hypotensive constituents from the pods of Moringa oleifera. Planta Medica 64, 225-228.

Friedrich, C. L., Moyles, D., Beveridge, T. J. and Hancock, R. E. (2000). Antibacterial action of structurally diverse cationic peptides on Gram-positive bacteria. Antimicrobial Agents and Chemotherapy 44, 2086-2092.

Farooq, F., Rai, M., Tiwari, V., Khan, A. A. and Farooq, S. (2012). Medicinal properties of Moringa oleifera: an overview of promising healer. Journal of Medicinal Plants Research 6(27), 4368-4374.

Farnaud, S., Spiller, C., Moriarty, L. C., Patel, A., Gant, V., Odell, E. W. and Evans, R. W. (2004). Interactions of lactoferricin-derived peptides with LPS and antimicrobial activity. FEMS Microbiology Letters 233, 193-199.

Folkard, G. and Sutherland, J. (2005). Moringa oleifera - a multi-purpose tree. Journal of Tropical Medicine and Hygiene 90, 101-109.

Fuglie, L. J. (1999). The miracle tree: Moringa oleifera: Natural nutrition for the tropics. Church World Service, Dakar. pp 68.

Gami, B. and Parabia, F. (2011). Screening of methanol and acetone extract for antimicrobial activity of some medicinal plant species of Indian folklore. International
Journal of Research in Pharmaceutical Sciences 2(1), 69-75.

Gibbons, S. and Udo, E. E. (2000). The effect of reserpine, a modulator of multidrug efflux pumps, on the in vitro activity of tetracycline against clinical isolates of methicillin resistant Staphylococcus aureus (MRSA) possessing the tet(K) determinant. Phytotherapy Research 14(2), 139-140.

Gill, A. O. and Holley, R. A. (2004). Mechanisms of bactericidal action of cinnamaldehyde against Listeria monocytogenes and of eugenol against $L$. monocytogenes and Lactobacillus sakei. Applied and Environmental Microbiology 70, 5750-5755.

Griffin, S. G., Wyllie, S. G., Markham, J. L. and Leach, D. N. (1999). The role of structure and molecular properties of terpenoids in determining their antimicrobial activity. Flavour and Fragrance Journal 14(5), 322-332.

Guevara, A. P., Vargar, C., Sakurai, H., Fujiwara, Y., Hashimoto, K., Maoka, T., Kozuka, M., Ito, Y., Tokuda, H. and Nishino, H. (1999). An antitumor promoter from Moringa oleifera Lam. Mutation Research 440(2), 181-188.

Harristoy, X., Fahey, J., Scholtus, I. and Lozniewski, A. (2005). Evaluation of antimicrobial effects of several isothiocyanates on Helicobacter pylori. Planta Medica 71, 326-330.

He, K., Ludtke, S. J., Heller, W. T. and Huang, H. W. (1996). Mechanism of alamethicin insertion into lipid bilayers. Biophysical Journal 71, 2669-2679.

He, K., Ludtke, S. J., Huang, H. W. and Worcester, D. L. (1995). Antimicrobial peptide pores in membranes detected by neutron in-plane scattering. Biochemistry 34, 15614-15618.

Heller, W. T., Waring, A. J., Lehrer, R. I., Harroun, T. A., Weiss, T. M., Yang, L. and Huang, H. W. (2000). Membrane thinning effect of the beta-sheet antimicrobial protegrin. Biochemistry 39, 139-145.

Hostettman, K. and Nakanishi, K. (1979). Moronic acid, a simple triterpenoid keto acid with antimicrobial activity isolated from Ozoroa mucroanta. Journal of Medicinal Plant Research 31, 358-366.

Jabeen, R., Shahid, M., Jamil, A. and Ashraf, M. (2008). Microscopic evaluation of the antimicrobial activity of seed extracts of Moringa oleifera. Pakistan Journal of Botany 40(4), 1349-1358.

Jain, A., Gupta, Y., Agrawal, R., Khare, P. and Jain, S. K. (2007). Biofilms - A microbial life perspective: A critical review. Critical Reviews in Therapeutic Drug Carrier Systems 24, 393-443.

Jamil, A., Shahid, M., Khan, M. and Ashraf, M. (2007). Screening of some medicinal plants for isolation of antifungal proteins and peptides. Pakistan Journal of Botany 39(1), 211-221.

Jennings, B. R. and Ridler, P. J. (1983). Interaction of chromosomal stains with DNA. Biophysics of Structure and Mechanism 10, 71-79.

Jerri, H. A., Adolfsen, K. J., McCullough, L. R., Velegol, D. and Velegol, S. B. (2012). Antimicrobial 
sand via adsorption of cationic Moringa oleifera protein. Langmuir 28, 2262-2268.

Kalpana, S., Moorthi, S. and Kumara, S. (2013). Antimicrobial activity of different extracts of leaf of Moringa oleifera (Lam) against Gram-positive and Gram-negative bacteria. International Journal of Current Microbiology and Applied Sciences 2(12), 514518.

Karou, D., Savadogo, A., Canini, A., Yameogo, S., Montesano, C., Simpore, J., Colizzi, V. and Traoer, A. S. (2005). Antibacterial activity of alkaloids from Sida acuta. African Journal of Biotechnology 4(12), 1452-1457.

Kerharo, P. J. (1969). Un remede populaire Sengalais: Le "Nebreday" (Moringa oleifera lann.) employes therapertiques en milieu Africain chimie et pharmacologie. Plantes Med Phytother 3, 14-219.

Khan, I. A., Mirza, Z. M., Kumar, A., Verma, V. and Qazi, G. N. (2006). Piperine, a phytochemical potentiator of ciprofloxacin against Staphylococcus aureus. Antimicrobial Agents and Chemotherapy 50, 810-812.

Khesorn, N. (2009). Antibacterial activity of the capsules of Moringa oleifera Lam. (Moringaceae). Journal of Ethnopharmacology 36, 233-237.

Korithu, D. P., Manivarnan, N. K., Gopinath, A. and Abraham, R. (2011). Antimicrobial evaluation, reducing power assay and phytochemical screening of Moringa oleifera leaf extracts: effect of solvent polarity. International Journal of Pharmaceutical Sciences and Research 2(11), 2991-2995.

Kostova, I. and Dinchev, D. (2005). Saponins in Tribulus terrestris - chemistry and bioactivity. Phytochemistry Reviews 4, 111-137.

Krygier, K., Sosulki, F. and Hogge, L. (1982). Free, esterifies and insoluble bound phenolic acids. 2. Composition of phenolic acids in rapeseed seed flour and hulls. Journal of Agricultural and Food Chemistry 30, 334-336.

Kudi, A. C., Umoh, J. U., Eduvie, L. O. and Gefu, J. (1999). Screening of some Nigerian medicinal plants for antibacterial activity. Journal of Ethnopharmacology 67, 225-228.

Kumbhar, M. R., Guleha, V. and Sivakumar, T. (2012). Estimation of total phenolic content, cytotoxicity and in vitro antioxidant activity of stem bark of Moringa oleifera. Asian Pacific Journal of Tropical Diseases 2(2), 144-150.

Lalas, S. and Tsaknis, J. (2002). Extraction and identification of natural antioxidants from the seeds of Moringa oleifera tree variety of Malavi. Journal of the American Oil Chemists' Society 79, 677-683.

Lalas, S., Gortzi, O., Athanasiadis, V., Tsaknis, J. and Chinou, I. (2012). Determination of antimicrobial activity and resistance to oxidation of Moringa peregrine seed oil. Molecules 17, 2330-2334.

Lar, P. M., Ojile, E. E., Dashe, E. and Oluoma, J. N. (2011). Antibacterial activity of Moringa oleifera seed extracts on some Gram-negative bacterial isolates. African Journal of Natural Sciences 14, 57-62.
Lee, J. H., Kim, M. S., Cho, J. H. and Kim, S. C. (2002). Enhanced expression of tandem multimers of the antimicrobial peptide buforin II in Escherichia coli by the DEAD-box protein and trxB mutant. Applied Microbiology and Biotechnology 58, 790-796.

Leven, M., Vanden, D. A. B., Mertens, F., Vlictinck, A. and Lammens, E. (1979). Screening of higher plants for biological activities. I. antimicrobial activity. Planta Medica 36(4), 311-321.

Li, Y. T., Kwon, Y. I., Labbe, R. G. and Shetty, K. (2005). Inhibition of Helicobacter pylori and associated urease by oregano and cranberry phytochemical synergies. Applied and Environmental Microbiology 71, 8558-8564.

Makkar, H. P. S. and Becker, K. (1996). Nutritional value and antinutritional components of whole and ethanol extracted Moringa oleifera leaves. Animal Feed Science and Technology 63, 211-228.

Makonnen, E., Hunde, A. and Damecha, G. (1997). Hypoglycaemic effect of Moringa stenopetala aqueous extract in rabbits. Phytotherapy Research 11, 147-148.

Mangale, S. M., Chonde, S. G. and Raut, P. D. (2012). Use of Moringa oleifera (Drumstick) seed as natural absorbent and an antimicrobial agent for groundwater treatment. Research Journal of Recent Sciences 1(3), 31-40.

Marrufo, T., Nazzaro, F., Mancini, E., Fratianni, F., Coppola, R., Martino, L. D., Agostinho, A. B. and Feo, V. D. (2013). Chemical composition and biological activity of the essential oil from leaves of Moringa oleifera Lam. cultivated in Mozambique. Molecules 18, 10989-11000.

Mashiar, M., Mominul, I., Sharma, A., Soriful, I., Atikur, R., Mizanur, R. and Alam, M. (2009). Antibacterial activity of leaf juice extracts of Moringa oleifera Lam. against some human pathogenic bacteria. Chiang Mai University Journal of Natural Sciences 8, 219-227.

Masika, M. B., Julius, P. and Voster, M. (2012). Antimicrobial activities of Moringa oleifera Lam leaf extracts. African Journal of Biotechnology 11(11), 2797-2802.

Mason, T. L. and Wasserman, B. P. (1987). Inactivation of red beet beta-glucan synthase by native and oxidized phenolic compounds. Phytochemistry 26, 2197-2202.

Matsuzaki, K., Murase, O., Fujii, N. and Miyajima, K. (1996). An antimicrobial peptide, magainin 2, induced rapid flip-flop of phospholipids coupled with pore formation and peptide translocation. Biochemistry 35, 11361-11368.

Maurya, S. K. and Singh, A. K. (2014). Clinical efficacy of Moringa oleifera Lam. stems bark in urinary tract infection. International Scholarly Research Notices 2014, 1-7.

Mehta, L. K., Balaraman, R., Amin, A. H., Bafna, P. A. and Gulati, O. D. (2003). Effect of fruits of Moringa oleifera on the lipid profile of normal and hypercholesterolaemic rabbits. Journal of Ethnopharmacology 86, 191-195. 
Mehta A. and B. Agrawal. (2008). Investigation into the mechanisms of action of Moringa oleifera for its antiasthamatic activity. Oriental Pharmacy and Experimental Medicine 8(1), 24-31.

Mendoza, L., Wilkens, M. and Urzua, A. (1997). Antimicrobial study of the resinous exudates and of diterpenoids and flavonoids isolated from some Chilean Pseudognaphalium (Asteraceae). Journal of Ethnopharmacology 58, 85-88.

Mirzoeva, O. K., Grishanin, R. N. and Calder, C. (1997). Antimicrobial action of propolis and some of its components: the effects on growth, membrane potential and motility of bacteria. Microbiological Research 152, 239-246.

Mishra, G., Singh, P., Verma, R., Kumar, S., Srivastav, S., Jha, K. K. and Khosa, R. L. (2011). Traditional uses, phytochemistry and pharmacological properties of Moringa oleifera plant: A overview. Der Pharmacia Lettre 3(2), 141-164.

Mori, A., Nishino, C., Enokib, N. and Tawatta, S. (1987). Antibacterial activity and mode of action of plant flavonoids against Proteus vulgaris and Staphylococcus aureus. Phytochemistry 26, 22312234.

Morton, J. F. (1991). The horseradish tree, Moringa pterigoserma (Moringaceae). A boon to arid lands. Economic Botany 45, 318-333.

Mossa, J. S. (1985). A study on the crude antidiabetic drugs used in Arabian folk medicine. International Journal of Crude Drug Research 23, 137-145.

Mughal, M. H., Ali, G., Srivastava, P. S. and Iqbal, M. (1999). Improvement of drumstick (Moringa pterygosperma Gaertn.) - A unique source of food and medicine through tissue culture. Hamdard Medicus 42, 37-42.

Nadkarni, A. K. (1976). Indian Materia Medica. Popular Prakashan: Bombay. pp. 810-816.

Nagar, P. K., lyer, R. I. and Sircar, P. K. (1982). Cytokinins in developing fruits of Moringa pterigosperma Gaertn. Physiologia Plantarum 55, 4550.

Nantanchit, K. (2006). Antibacterial activity of the capsules of Moringa oleifera Lamk. (Moringaceae). Chiang Mai University Journal of Natural Sciences 5(3), 365-368.

Negi, P. S. (2012). Plant extracts for the control of bacterial growth: Efficacy, stability and safety issues for food application. International Journal of Food Microbiology 156, 7-17.

Newman, D. J., Cragg, G. M. and Snader, K. M. (2000). The influence of natural products upon drug discovery. Natural Product Reports 17, 215-234.

Nepolean, P., Anitha, J. and Renitta, R. E. (2009). Isolation, analysis and identification of phytochemicals of antimicrobial activity of Moringa oleifera Lam. Current Biotica 3(1), 33-39.

Nikaido, H. and Vaara, M. (1985). Molecular basis of bacterial outer membrane permeability. Microbiological Reviews 49(1), 1-32.
Nikkon, F., Saud, Z. A., Rehman, M. H. and Haque, M. E. (2003). In vitro antimicrobial activity of the compound isolated from chloroform extract of Moringa oleifera Lam. Pakistan Journal of Biological Sciences 22, 1888-1890.

Nwosu, M. and Okafor, J. (1995). Preliminary studies on antifungal activities of some medicinal plants against Basidiobolus and some other pathogenic fungi. Mycoses 38, 191-195.

Okiki, A. P., Balogun, B. D., Osibote, I. A., Asoso, S. and Olufunke, A. (2015). Antibacterial activity of methanolic extract of Moringa oleifera Lam. leaf on ESBL producing bacterial isolates from urine of patients with urinary tract infections. Journal of Biology, Agriculture and Healthcare 5(20), 124-132.

Onsare, J. G. and Arora, D. S. (2014). Antibiofilm potential of flavonoids extracted from Moringa oleifera seed coat against Staphylococcus aureus, Pseudomonas aeruginosa and Candida albicans. Journal of Applied Microbiology 118, 313-325.

Oren, Z. and Shai, Y. (1998). Mode of action of linear amphipathic alphahelical antimicrobial peptides. Biopolymers 47, 451-463.

Padla, E. P., Solis, L. T., Levida, R. M., Shen, C. C. and Raqasa, C. Y. (2012). Antimicrobial isothiocyanates from the seeds of Moringa oleifera Lam. Zeitschrift fur Naturforschung C 67(11-12), 557-558.

Padmarao, P., Acharya, B. M. and Dennis, T. J. (1996). Pharmacognostic study on stembark of Moringa oleifera Lam. Bulletin of Medico-Ethno-Botanical Research 17, 141-151.

Paiva, P. M. G., Gomes, F. S., Napoleao, T. H., Sa, R. A., Correia, M. T. S. and Coelho, L. C. B. B. (2010). Antimicrobial activity of secondary metabolites and lectins from plants. Current research, technology and education topics in applied microbiology and microbial biotechnology (Méndez-Vilas, A. Ed.). Formatex. pp. 396-406.

Palada, M. C. and Changi, L. C. (2003). Suggested cultural practices for Moringa. International Cooperators' Guide AVRDC. AVRDC pub \# 03-545 (www.avrdc.org).

Palombo, E. A. and Semple, S. J. (2001). Antibacterial activity of traditional Australian medicinal plants. Journal of Ethnopharmacology 77, 151-157.

Peixoto, J. R. O., Silva, G. C., Costa, R. A., Fontenelle, J. L. D. S., Vieira, G. H. F., Filho, A. A. F. and Vieira, R. H. S. D. S. (2011). In vitro antibacterial effect of aqueous and ethanolic Moringa leaf extracts. Asian Pacific Journal of Tropical Medicine 4(3), 201-204.

Pearce, G., Moura, D. S., Stratmann, J. and Ryan, C. A. (2001). Production of multiple plant hormones from a single polyprotein precursor. Nature 411(6839), 817820.

Plaper, A., Golob, M., Hafner, I., Oblak, M., Solmajer, T. and Jerala, R. (2003). Characterization of quercetin binding site on DNA gyrase. Biochemical and Biophysical Research Communications 306(2), 530536. 
Pouny, Y., Rapaport, D., Mor, A., Nicolas, P. and Shai, Y. (1992). Interaction of antimicrobial dermaseptin and its fluorescently labeled analogues with phospholipid membranes. Biochemistry 31, 12416-12423.

Qaiser, M. (1973). Moringaceae. In: Flora of West Pakistan. Nasir, E. and Ali, S. I. (eds). Ed. 38. University of Karachi press: Karachi. pp. 1-4.

Raj, A. J., Gopalakrishnan, V. K., Yadav, S. A. and Dorairaj, S. (2011). Antimicrobial activity of Moringa oelifera (Lam.) root extract. Journal of Pharmacy Research 4(5), 1426 - 1427.

Ramachandran, C., Peter, K. V. and Gopalakrishnan, P. K. (1980). Drumstick (Moringa oleifera): A multipurpose Indian vegetable. Economic Botany 34, 276-283.

Ramey, B. E., Koutsoudis, M., von Bodman, S. B. and Fuqua, C. (2004). Biofilm formation in plant-microbe associations. Current Opinion in Microbiology 7, 602609.

Rao, V. A., Devi, P. U. and Kamath, R. (2001). In vivo radioprotective effect of Moringa oleifera leaves. Indian Journal of Experimental Biology 39, 858-863.

Renitta, R. E., Anitha, J. and Napolean, P. (2009). Isolation, analysis and identification of phytochemicals of antimicrobial activity of Moringa oleifera Lam. Current Biotica 3(1), 33-37.

Ruckmani, K., Kavimani, S., Anandan, R. and Jaykar, B. (1998). Effect of Moringa oleifera Lam. on paracetamol-induced hepatoxicty. Indian Journal of Pharmaceutical Sciences 60(1), 33-35.

Saadabi, A. M. and Abu, I. E. Z. (2011). An in vitro antimicrobial activity of Moringa oleifera L. seed extracts against different groups of microorganism. Australian Journal of Basic and Applied Sciences 5(5), 129-134.

Scalbert, A. (1991). Antimicrobial properties of tannins. Phytochemistry 30(12), 3875-3883.

Shahidi, F., Janitha, P. K. and Wanasundara, P. D. (1992). Phenolic antioxidants. Critical Reviews in Food Science and Nutrition 32, 67-103.

Siddhuraju P. and K. Becker. (2003). Antioxidant properties of various solvent extracts of total phenolic constituents from three different agro-climatic origins of drumstick tree (Moringa oleifera Lam.). Journal of Agricultural and Food Chemistry 15, 2144 - 2155.

Sikkema J., de Bont, J. A. M. and Poolman, B. (1995). Mechanisms of membrane toxicity of hydrocarbons. Microbiological Reviews 59, 201-222.

Silvestro, L., Weiser, J. N. and Axelsen, P. H. (2000). Antibacterial and anti-membrane activities of cecropin A in Escherichia coli. Antimicrobial Agents and Chemotherapy 44, 602-607.

Simões, M., Cleto, S., Rocha, S., Coimbra, M. A. and Vieira, M. J. (2008). Enhancement of Escherichia coli and Staphylococcus aureus antibiotic susceptibility using sesquiterpenoids. Medicinal Chemistry 4, 616623.

Simões, M., Bennett, R. N. and Rosa, E. A. S. (2009). Understanding antimicrobial activities of phytochemicals against multidrug resistant bacteria and biofilms. Natural Product Reports 26, 746-757.

Singh, R. S. G., Negi, P. S. and Radha, C. (2013). Phenolic composition, antioxidant and antimicrobial activities of free and bound phenolic extracts of Moringa oleifera seed flour. Journal of Functional Foods 5, 1883-1891.

Spiliotis, V., Lalas, S., Gergis, V. and Dourtoglou, V. (1997). Comparison of antimicrobial activity of seeds of different Moringa oleifera varieties. Pharmacy and. Pharmacology Letters 7, 39-40.

Stavri, M., Piddock, L. J. and Gibbons, S. (2007). Bacterial efflux pump inhibitors from natural sources. The Journal of Antimicrobial Chemotherapy 59(6), 1247-1260.

Suarez, M., Entenza, J. M., Doerries, C., Meyer, E., Bourguin, L., Sutherland, J., Marison, I., Moreillon, P. and Mermod, N. (2003). Expression of a plantderived peptide harboring water-cleaning and antimicrobial activities. Biotechnology and Bioengineering 81, 13-20.

Suarez, M., Haenni, M., Canarelli, S., Fisch, F., Chodanowski, P., Servis, C., Michielin, O., Freitag, R., Moreillon, P. and Mermod, N. (2005). Structurefunction characterization and optimization of a plantderived antibacterial peptide. Antimicrobial Agents and Chemotherapy 49(9), 3847-3857.

Tachi, T., Epand, R. F., Epand, R. M. and Matsuzaki, K. (2002). Position dependent hydrophobicity of the antimicrobial magainin peptide affects the mode of peptide-lipid interactions and selective toxicity. Biochemistry 41, 10723-10731.

Talreja, T. (2010). Screening of crude extract of flavonoids of Moringa oleifera against bacteria and fungal pathogen. Journal of Phytology 2(11), 31-35.

Talreja, T., Yadav, L., Sharma, K. and Goswami, A. (2012). Flavonoids from some medicinal plants in vivo and in vitro. The Bioscan 7(1), 157-159.

Tam, J. P., Yi-An, L. and Jin-Long, Y. (2002). Antimicrobial dendrimeric peptides. European Journal of Biochemistry 269, 923-932.

Tepe, B., Daferera, D., Sokmen, A., Sokmen, M. and Polissiou, M. (2005). Antimicrobial and antioxidant activities of the essential oil and various extracts of Salvia tomentosa Miller (Lamiaceae). Food Chemistry 90, 333-340.

The Wealth of India. 1962. A Dictionary of Indian raw materials and industrial products. Raw materials. Vol. VI: L-M; Council of Scientific and Industrial Research: New Dehli. pp. 425-429.

Tholl, D. (2006). Terpene synthases and the regulation, diversity and biological roles of terpene metabolism. Current Opinion in Plant Biology 9(3), 297-304.

Tortora, G. F., Funke, B. R. and Case, C. L. (2001). Microbiology: an introduction. 7th ed. San Francisco: Benjamin Cummings.

Tsaknis, J., Lalas, S., Gergis, V., Dourtoglou, V. and Spiliotis, V. (1999). Characterization of Moringa oleifera variety Mbololo seed oil of Kenya. Journal of Agricultural and Food Chemistry 47, 4495-4499. 
Malays. J. Microbiol. Vol 15(3) 2019, pp. 244-259

DOI: http://dx.doi.org/10.21161/mjm.113117

Vaghasiya, Y. and Chanda, V. (2007). Screening of methanol and acetone extracts of fourteen Indian medicinal plants for antimicrobial activity. Turkish Journal of Biology 31, 243-248.

Vieira, G. H. F., Mourão, J. A., Ângelo, Â. M., Costa, R. A., and Vieira, R. H. S. D. F. (2010). Antibacterial effect (in vitro) of Moringa oleifera and Annona muricata against Gram-positive and Gram-negative bacteria. Revista do Instituto Medicina Tropical de São Paulo 52(3), 129-132.

von Maydell, H. J. (1986). Trees and shrubs of Sahel, their characterization and uses. Deutsche Gesellschaft fur Technische Zusammenarbeit, Germany: Eschborn 334-337.

Walter, A., Samuel, W., Peter, A. and Joseph, 0. (2011). Antibacterial activity of Moringa oleifera and Moringa stenopetala methanol and $\mathrm{n}$-hexane seed extracts on bacteria implicated in water borne diseases. African Journal of Microbiology Research 5(2), 153-157.

Yu, J., Vasanthan, T. and Tamelli, F. (2001). Analysis of phenolic aicds in barley by high-performance liquid chromatography. Journal of Agricultural and Food Chemistry 49, 4352-4360.

Zaffer, M., Ahmad, S., Sharma, R., Mahajan, S., Gupta, A. and Agnihotri, R. K. (2014). Antibacterial activity of bark extracts of Moringa oleifera Lam. against some selected bacteria. Pakistan Journal of Pharmaceutical Sciences 27(6), 1857-1862.

Zhang, L., Rozek, A. and Hancock, R. E. W. (2001). Interactions of cationic antimicrobial peptides with model membranes. The Journal of Biological Chemistry 276, 35714-35722. 